\title{
A single battery bank, three-phase cascaded multilevel inverter with the least number of conducting switches
}

\begin{abstract}
The world energy sector nowadays are moving from fossil fuel energy generation towards renewable energy systems. Hence the rise of battery cells technology and with it the multilevel inverter. Three originally main multilevel inverter categories are cascaded $\mathrm{H}$ bridge inverter, flying capacitor inverter and neutral point clamped inverter. Due to its modular structure and easily configured into multi-sources systems such as photovoltaic array, the cascaded H-bridge inverter is thriving in the renewable energy sector. However the downside of cascaded H-bridge inverter is the need for large number of switches, and this is evident in three phase design. The other problem is the amount of switches that have to be turned on during operation are high, thus resulting in voltage drops accumulations internally, causing losses and increase inefficiency. In this paper, a single battery bank, three phase multilevel inverter general topology with only three conducting ideal switches during operation is proposed. A 41-level version of the topology is built and simulated in Matlab Simulink platform. The result shows that the proposed inverter topology has a minimal output THD level and low internal voltage losses.
\end{abstract}

Keyword: Three phase inverter; Multilevel inverter; Neutral line stability; Conducting switch 